\title{
The Materiality Judgment Gap: An experimental study
}

\author{
By \\ Maha Mamdouh Hashem \\ Demonstrator \\ Accounting department \\ Faculty of commerce - Zagazig University
}




\begin{abstract}
The Securities and Exchange Commission (SEC) has expressed concern that auditors' use of materiality allows misstatements to go uncorrected. Auditors do not require their client to correct the financial statements for immaterial misstatements. According to the professional standards, an immaterial misstatement is defined as one that has no effect on average user's decisions. However, little is known about users' materiality perceptions and what is considered to be material from user's point of view. This study investigates auditors' and users' materiality decisions by conducting three experimental cases to examine auditors' and users' assessments of materiality. Since materiality choices are not disclosed in the auditors' report or elsewhere, users of financial statements have no information as to the precision of the balances shown. Several regulations have proposed that auditor should be required to disclose his materiality threshold to users. To date, this proposal has not been enforced. This study also investigates the extent to which users of the financial statements find the disclosure of auditor materiality threshold useful. The results suggest that significantly different views of materiality exist across different cases. Understandably, users demonstrate lower materiality threshold than auditors. Materiality judgment gap does exist between auditors and users of financial statements. The results also suggest that there is a strong agreement among users with auditor materiality disclosure as a possible way to alleviate the impact of the materiality judgment gap as it facilitates users' perceptions of the accuracy of the auditor's report, and reduces overconfidence behavior in investment decision.
\end{abstract}

Key words: materiality, materiality threshold, judgment gap, materiality disclosure. 


\section{Introduction}

The financial statements preparation is the responsibility of management who provides them to stakeholders such as shareholders, boards of directors, regulators and other third parties who may depend on the financial statements for making decisions. However, management has goals that may differ from the goals of the stakeholders. Because of the conflict of interests between management and users of the financial statements those users cannot just rely on the financial statements prepared by management without being verified by an independent third party, i.e., the auditor. The auditor's task is to assess, on behalf of the shareholders, whether management prepares the financial statements in conformity with applicable GAAP.

Materiality concept is one of the most important concepts of auditing. The materiality concept should be considered by the auditor before making an opinion about the financial statements. Technical standards do not provide specific guidance to auditors regarding making materiality assessment. In fact, the Financial Accounting Standards Boards states: "No general standards of materiality can be formulated to take into account all the considerations that enter into an experienced human judgment (FASB, 1980, p.xiii)". The Auditing Standards Board echoes this belief in SAS 47, noting that: "The auditor's consideration of materiality is a matter of professional judgment.... (AICPA,1984, Para. 6)". The most specific guidance provided in the Statements on Auditing Standards (SAS) No. 47 is a comment that materiality consideration will vary with the size and complexity of the entity, as well as with the auditor's knowledge of the auditee (AICPA, 1984, Para. 11). 
There are no sets of rules or prescriptions that may be applied consistently to determine materiality in all circumstances. Materiality is a relative term. What may be material in one circumstance may not be material in another. The assessment of what is material is a matter of professional judgment and experience of the auditor.

Materiality has been and continues to be a topic of importance for auditors. The most recent controversy started when Securities and Exchange Chairman Arthur Levitt expressed concern over the concept of materiality in financial reporting and auditing in his "Number Game" speech (1998). He argued that measures may not be appropriate in today's capital market structure because companies and their auditors were misusing the concept of materiality in order to "manage" earnings. Commissioner Levitt stated that:

"However some companies misuse the concept of materiality. They intentionally record errors within a defined percentage ceiling. They then try to excuse that fib by arguing that the effect on the bottom line is too small to matter. If that is the case, why do they work so hard to insert those errors? May be because the effect can matter. When either management or the external auditors are questioned about these clear violations of GAAP, they answer "It does not matter, it's immaterial".

Generally, immaterial items are not reported separately in financial statements and are not explicitly part of the information set available to investors, creditors and other users of accounting information. Thus, judgments regarding materiality determine, in part, the content of financial statements. There are few instances in which financial reporting and auditing standards provide explicit operational guidance on materiality. Also, due to 
archival data- availability constraints, most empirical evidence on materiality has been obtained through surveys and laboratory experiments, with little evidence on the outcomes of auditors' implied materiality judgments . (Chewing, et al.,1998).

It is important that materiality judgment be aligned with investor needs. In particular, there should be additional emphasis on the role of qualitative factors in evaluating materiality from the investor's perspective. Qualitative factors, when viewed from the investor's perspective, may very well indicate that an error that is relatively large in magnitude is immaterial (John, 2007).

\section{Problem Statement}

"The whole accounting mess can be cleared up by simply defining the word materiality" (Kessler, 2001). The collapse of Enron and the associated problems with its accounting and auditing have resulted in an increased awareness of the issue of financial statements materiality. Part of the problem results from the fact that establishing materiality relies on the professional judgment of the auditor. Statement on Auditing Standards (SAS) No. 47, Audit Risk and Materiality in conducting an audit (AICPA 1983, AU 312) provides no computational guidance and simply quotes statement of financial accounting concepts (SFAC) No. 2 (FASB 1980) which describes an item as material when it is "probable that the judgments of a reasonable person would have been changed or influenced by the inclusion or correction of the item" (para. 132). The Securities and Exchange Commission (SEC) has shown substantial concern that materiality choice has allowed management of public companies to "manage" earnings and that auditors have allowed this to happen through lax judgments. 
Information is material if its omission or misstatement could influence the economic decisions of users made on the basis of the financial statements. As long as misstatements do not violate the fair view of financial statements and give the fair financial position of a company, they are considered immaterial (Nivra, 2007). It is the responsibility of the auditor to be reasonably sure about the fairness of the financial statements in all material aspects.

Lacking detailed external, operational guidance, auditors have relied on "judgment" or resorted to internally generated rules of thumb (RTs). These RTs are conventions developed through years of practice. Since experience varies, RTs used in the profession naturally would be expected to vary. RTs may be internal and unique to the individual auditor or they may be common to a local office or to a firm- wide practice.

Materiality is problematic since it requires professional judgment about the relative importance and effect of financial reporting and disclosure choices on the decisions of the users of financial statements. While accountant's materiality judgments are mainly disclosure-related, auditor's materiality judgments affect both the amount of work done by the auditor and the disclosure made or not made in the financial statements (Mckee and Eilifsen, 2000).

Because the user is the one who is presumed to make decisions based on the financial statements information, in theory it should be the user of the financial statements who decides what is material and what is not material. In practice, auditors make risk / assurance and materiality determination without the consent of users, based upon assumptions about users' need. 
The paradox of materiality is that, it is the auditor who assesses what is material or immaterial for users of the financial statements, but does the auditor really know what users regard as material or immaterial? (Hojskov, 1998).Yet, some issues that an auditor deems immaterial may be very material to investors and others (Kranacher, 2007). Many studies call into question whether a majority of CPAs can accurately assess what users need.

The users of financial statements expect that the auditors' materiality levels correspond with their own. However, the widespread litigation against auditors indicates that there is a gap between society's expectations of auditors and auditors performance (Porter, 1993), especially if the financial statements contain non-corrected known errors classified as immaterial by the auditor, but are (or may be) classified as material by the users.

Therefore the research problem can be stated in the following questions:

1- Does the auditor's assessment of materiality differ from the user's assessment of materiality which may lead to a materiality judgment gap? and,

2- If so, does the disclosure of materiality level used by the auditor will be helpful to users as a way to alleviate the impact of the materiality judgment gap.

\section{Research Objectives}

The purpose of this study is to (a) compare materiality levels among two user groups (financial analysts and credit mangers) and auditors to determine whether the auditors' materiality levels differ from those of users' materiality levels which can lead to a materiality judgment gap, and (b) identify whether the disclosure of materiality level used by the auditor will be helpful to users as a way to alleviate the impact of the gap, if exist. 
Many studies emphasize the importance of considering materiality from the perspective of users (investors). Users' perspective is the key element in materiality determination in applying judgment to determine how to address materiality. Some studies send a message to auditors which is "know your user" then ask yourselves an important question 'would my user come to a different conclusion if I used some other materiality standard?'

If auditors' materiality threshold is set higher than users' threshold, then useful financial information may be omitted from financial reports and significant misstatements may exist in the financial statements without being corrected. In these situations, the audit becomes an ineffective means of controlling agency costs (Kinney et al., 2002).

Therefore, the existence of an expectation gap regarding materiality might contribute to a reduction of the perceived value of the auditor' opinion as regards the true and fair view of the financial statements of a company which is not in the interest of users and auditors. Hence, it is important to take into consideration materiality from the users' perspective and to know whether a relevant expectation gap regarding materiality exists and, if so, the way to narrow it. Accordingly, this study examines materiality from the users' perspective, auditors' and users' materiality assessments (threshold), and investigates the extent to which users of the financial statements accept the disclosure of auditor materiality threshold.

Briefly, I find that there is a significant different between auditor's assessment and users' assessments of materiality threshold which lead us to a materiality judgment gap. Results documented that users demonstrate lower materiality threshold than auditors. The results also suggest that providing users of financial statements with the auditor materiality threshold narrows 
materiality judgment gap as it increases users' perceptions of the accuracy of the auditor's report, and reduces overconfidence behavior in investment decision.

The rest of the paper is structured as follows. The second section provides a brief overview of the materiality and its definition, new auditing standards related to materiality. The third section discusses materiality judgment gap in the previous studies, develops research hypotheses and the disclosure of materiality as appeared in various studies. The fourth section presents the experimental study, followed by section 5 which discusses the results, and closes with conclusion of the results, and future research.

\section{Materiality}

Materiality is a key concept in both the theory and practice of accounting and auditing. The importance of this issue is summarized in Financial Accounting Standards Board's Discussion Memorandum " The concept of materiality pervades the financial accounting and reporting process". It influences decisions regarding the collection, classification, measurement and summarization of data concerning the results of an enterprise's economic activities. It also bears on decisions concerning the presentation of that data and the related disclosures in financial statements.

The concept of materiality has been defined by the FASB in Statement of Financial Accounting Concepts No. 2 (FASB 1980, 132) as

" The omission or misstatement of an item is material in a financial report, if, in light of surrounding circumstances, the magnitude of the item is such that it is probable that the judgment of a reasonable person relying upon the report would have been changed or influenced by the inclusion or correction of an item". 


\subsection{Overview of new auditing standards related to materiality}

Little guidance is provided in both financial accounting standards and auditing standards on how to operationalize the concept of materiality. Materiality tends to be considered in quantitative terms only. The "traditional" approach in assessing materiality has been dominantly quantitative. That is, materiality judgments are made in terms of certain quantitative variables that are used to establish numerical benchmarks. As thresholds, these serve to distinguish the significance of audit-detected misstatements. Therefore, the distinction auditors make between material and immaterial misstatements depends almost exclusively on their amount.

Levitt (1998) was the first to sound the alarm on this erroneous and often deceptive practice in a speech suggestively titled The Numbers Game. The president of the SEC showed a strong preoccupation with the common practice in the business world of manipulating company earnings. After Levitt's speech, the SEC (1999) issued Staff Accounting Bulletin (SAB) No. 99, materiality, providing guidance on how to evaluate materiality. SEC has said that quantitative measures of materiality should not be slavishly adhered to and qualitative factors (e.g., the effect of the item on meeting consensus forecasted earnings, trend in earnings) should be taken into account in determining what material is.

Some years later, SAB 99 was taken into consideration by the International Auditing and Assurance Standards Board (IAASB 2002), when an important revision process was set in motion on International Standard of Auditing (ISA) 320, Audit Materiality. The aim of this process was to update the requirements and guidelines that frame the proper use of materiality in auditing. The International Federation of Accountants (IFAC) is also re- 
examining its guidance on materiality. Through its IAASB, it published an exposure draft in December 2004 to revise ISA 320 Audit Materiality. The exposure draft not only considers the size of an item, but also its nature and the circumstances of the entity when determining materiality and evaluating misstatements.

There has been a renewed interest in the concept of materiality motivated by concerns at the SEC, the Sarbanes-Oxley Act, the Auditing Standards Board (ASB), and International Auditing and Assurance Standards Board issuance of proposed standards on materiality. The IAASB, U.S. ASB, and the Public Company Accounting Oversight Board (PCAOB) have recently issued standards related to materiality. Professional and regulatory initiatives (Big Five Materiality Task Force 1998; SEC 1999; APB 2001) as well as the concerns of auditor abuses of the materiality concept (e.g., Levitt 1998) have influenced the development of these standards (Messier and Eilifsen, 2014). These standards prescribe a more comprehensive framework for materiality judgments than the prior standards. First, they include expanded requirements for consideration of the needs of the users of audited financial statements. Second they provide more guidance on determining levels of materiality, including how the nature of the entity and the entity' circumstances affect materiality. Third, there is expanded guidance on evaluating misstatements, including revising materiality as the audit progresses if the circumstances require and the consideration of the effect of undetected misstatements when considering uncorrected detected misstatements (Messier and Eilifsen, 2014).

Materiality is applied by the auditor in planning and performing the audit; evaluating the effect of identified and uncorrected misstatements; considering the possibility of undetected misstatements; and in forming the 
opinion in the auditor's report. Table 1 presents a list of the auditing standards based on the three phases of the materiality process.

Table (1) ${ }^{(1)}$

New auditing standards related to materiality

\begin{tabular}{|l|c|c|}
\hline $\begin{array}{l}\text { Consideration of Materiality in Planning and Performing an } \\
\text { Audit. }\end{array}$ & AS11 & \multirow{2}{*}{ PCAOB } \\
\cline { 1 - 2 } Evaluating Audit Results. & AS14 & \\
\hline Materiality in Planning and Performing an Audit. & AU-C 320 & \multirow{2}{*}{ ASB } \\
\cline { 1 - 2 } Evaluation of Misstatements Identified During the Audit. & AU-C 450 & \\
\cline { 1 - 2 } Materiality in Planning and Performing an Audit. & ISA 320 & \multirow{2}{*}{ IAASB } \\
\cline { 1 - 2 } Evaluation of Misstatements Identified During the Audit. & ISA 450 & \\
\hline
\end{tabular}

The Financial Crisis of 2008 brought into sharp focus the concerns of investors and others about the effectiveness of company stewardship. In particular, concerns were raised about whether the binary (i.e. pass/fail) auditor's report continued to be fit for the purpose of providing adequate transparency about the audit and the auditor's insights about the company. The FRC's response was to seek to improve company stewardship through coordinated changes to the UK Corporate Governance Code (the Code) and to Auditing Standards.

The FRC's response was to introduce new requirements for auditor's reports on companies subject to the Code. In June 2013, the FRC issued a revised version of ISA 700. The Auditing Practices Board has not adapt ISA 700, "Forming an Opinion and Reporting on Financial Statements," as issued by the IAASB. It has instead issued a clarified version of the recently revised

1- The effective dates for the IAASB, PCAOB, and ASB standards are December 15, 2009, December 15, 2010, and December 15, 2012, respectively. 
ISA (UK and Ireland) 700, "The Auditor's Report on Financial Statements," which addresses the requirements of Company Law and also provides for a more concise auditor's report. The main effect of this is that the form of the UK and Ireland auditor's reports may not be exactly aligned with the precise format of auditor's reports required by ISA 700 issued by IAASB. However, ISA (UK and Ireland) 700 has been designed to ensure that compliance with it will not preclude the auditor from being able to assert compliance with the ISAs issued by the IAASB. The auditor was required to report on the "fair, balanced and understandable" statement and on the report on the work of the Audit Committee, and to provide greater transparency about the audit. Greater transparency was addressed by requiring auditors to include within their reports: (Par. 19A, p 6)

a) A description of those assessed risks of material misstatement that were identified by the auditor and which had the greatest effect on the overall audit strategy; the allocation of resources on the audit; and directing the efforts of the engagement team؛

b) An explanation of how the auditor applied the concept of materiality in planning and performing an audit; and

c) A summary of the audit scope, including an explanation of how the scope was responsive to the assessed risks of material misstatement.

\section{Literature review and research hypotheses}

\subsection{Materiality threshold judgment}

In reviewing the empirical research on materiality judgment, the previous literature could be categorized based on (1) the general type of research method employed (survey/ questionnaire, judgment-capturing experiments, or archival research), and (2) the type of respondent group being 
investigated (users, auditors, or comparative studies of users, auditors, and preparers) .This classification is somewhat arbitrary and is solely for exposition purposes. The overlap between the two different classes is unmistakable.

\subsubsection{Research method employed}

\subsection{1-a Questionnaire surveys}

One of the earliest empirical studies of materiality was conducted by Woolsey (1954 a, 1954 b). He mailed questionnaire cases to national and nonnational CPAs, controllers, bankers, investment bankers, and academicians. Each case contained up to six situations in which the respondent was asked to indicate if the item in question (e.g., loss caused by an earthquake or disclosure of long-term leases) was material. He found that the materiality decision of an event is based on the percentage of the event of current income, suggesting that the materiality thresholds are between $5 \%$ to $15 \%$ of income before tax. Also, he found that national CPAs have higher materiality thresholds than local and regional CPAs.

The respondent was also requested to indicate the factor he considered most important in his decision process. In five of the six cases reported, the relationship of the item to current income was considered most important. The study also indicated a wide range of materiality thresholds among the groups surveyed.

Pattillo (1976) attempted to find the important factors in the materiality judgment process. Questionnaire cases were mailed to six groups: (1) financial executives in "fortune 500" firms; (2) financial executives not in "fortune 500" firms; (3) bankers; (4) financial analysts; (5) public accountants; and (6) accounting academicians. He found that there were "observable and 
significant differences in the materiality evaluations among the participants in the six groups, reflecting their dissimilar perspectives and objectives". The groups' means, as a percent of net income, ranged from $5.2 \%$ to $8.3 \%$. Financial analysts had the lowest mean while financial executives of large firms had the highest mean. Pattillo also found some interesting results within groups. The preparer group (financial executives) showed a relatively high level of uniformity in their materiality judgments. This departed from the user group, who displayed a wide range of opinions about their materiality thresholds. The nature of the judgment item, the relation of the judgment item to net income, and the absolute dollar amount of the judgment item were found to be the most important factors in the participant' decisions.

More recently, De Rooij (2009) attempted to discover what users needed regarding materiality, and to investigate the existence of an expectation gap between auditors and users of financial statements in materiality judgment. The issues concerning materiality that might contribute to an expectation gap were structured into possible measures (solutions) to improve the concept of materiality to users. A suitable way to discover what users need regarding materiality and how to narrow the possible expectation gap is to consult the users themselves. Two questionnaires (part one and part two) were developed and mailed to a variety of users of financial statements of listed companies (shareholders and creditors).

The first part consisted of a questionnaire with questions about the respondent and his position and general open-ended questions about his knowledge and his perception of materiality of misstatements. The second questionnaire consisted of close-ended questions (statements) about the desirability of the different materiality measures, the measures were briefly 
described and the respondent needed to choose the desirable measures. In the first part of the survey, more than half of the respondents who claimed to have (some) insight in which way the auditor applies materiality in practice, indicated that in order to judge financial statements well it is important to have knowledge about materiality. It appeared that a considerable number (at least $35 \%$ ) of respondents was not informed about the concept of materiality.

In the second part of the survey, it turned out that many of the respondents, the ones that were knowledgeable of the materiality concept before hand as well as the ones that were not, are of the opinion that the concept of materiality can be improved by introducing one or more measures, $43 \%$ of the respondents indicated agreements with changes regarding the concept. These results indicate that a relevant expectation gap regarding materiality exists between the respondents and auditors.

Also the study pointed out that, in general, respondents seemed to trust the materiality assessment the auditor executes. Therefore, it is concluded that the expectation gap regarding materiality does exist but is not significant.

\subsection{1-b Judgment-capture experiments}

Firth (1979) conducted an experiment to study and compare the materiality disclosure / judgments of 150 subjects composed of; 30 auditors from each of three big eight accounting firms in the U.K., 30 chief accountants in industrial and commercial firms, and 30 investment analysts and bank lending officers. Firth presented subjects with 30 cases (based upon published financial statements of 30 public companies) that included an interjected extraordinary item that was experimentally varied with respect to its effect on six variables (income, net assets, total assets, the firm's market capitalization, 
sales, and current assets). Results indicated significant differences between users, producers, and auditors with respect to the number of cases in which disclosure was judged to be necessary.

Højskov (1998) compared the materiality levels of 13 financial analysts, who represented professional investors / advisors and 11 state authorized public accountants of listed companies, to determine whether the auditors' materiality levels are in accordance with financial analysts'. It appears to have an expectation gap in a significant way.

Tuttle et al., (2002) conducted a series of experimental markets in which individual participants were given laboratory money and stock that they could use to trade with each other. These markets were similar to organized securities exchanges, but they were conducted via a computer and within a laboratory setting. This allowed them to control the information available to the participants, who based their trading on summaries of actual companies' financial statements, along with industry and prior year stock price data.

In some cases, they inserted misstatements into the financial statements; in other cases the statements were free of misstatement. For cases that were free of misstatement, the laboratory market prices closely followed the prices for these same companies on the NYSE. Laboratory prices for cases with misstatement at or below materiality thresholds auditors often use were not different from the same cases with no misstatement. Only when misstatements are above these thresholds do laboratory market prices diverge from the no misstatement case. It was found that non-professional investors don't trade according to standard, quantitative thresholds of materiality employed by auditors. The results suggest that materiality levels auditors use are generally appropriate and that undisclosed misstatements within these levels have no 
detectable effect on market prices. They found no support for the viewpoints of some regulators and courts that would treat every misstatement as "material". They further concluded that auditors appear to be conservative in their application of materiality.

\subsection{1-c Archival studies}

Jennings et al. (1987) conducted an experiment to assess the degree of consensus on various disclosure issues existing both within and among: (1) CPAs,(2) various user groups, and (3) officers of the court. They examined and compared the responses of officers of the court with those of auditors to selected materiality questions to assess whether current audit practice differs from the courts' assessments of investors' needs. The findings showed significantly different views of materiality existed across cases and there was high variation between the groups in determining materiality.

In a related study, Jennings et al. (1991) investigated auditors' and judges/ lawyers' attitudes toward materiality and disclosure judgments. They found that the attitudes of judges/ lawyers differed substantially from auditors, with the judges/lawyers exhibiting higher standards of disclosure.

\subsection{1-d Type of respondent groups}

Chewing et al. (1998) compared investors and auditors judgments about materiality. They used a methodology that allowed them to infer their implied judgments from the data. In an archival - based approach, they examined the classification of gains (from equity - for - debt swaps) as ordinary or extraordinary and derive an implied auditor materiality judgment by comparing amount with income. In this regard, they found auditors and investors judgments to be similar. 


\section{Summary of Previous Literature}

To summarize, auditors have to use professional judgment to translate complex qualitative information into a quantitative measure; hence, varying perceptions of materiality arise (Turner, 2003; Kaplan and Reckers, 1995). There is a demonstrated difference in materiality thresholds between auditing firms of different size, auditors and investors; and management; and investors which may indicate the existence of the materiality judgment gap between financial statements users and auditors. The materiality judgment gap implies that the materiality criteria generally applied by auditors to define and operationalize materiality is quite different from the criteria applied by users of the client financial statements. This lack of consistency in materiality judgments prevents users from being aware of omissions or misstatements of items they may deem material (Davis, 2003).

\section{2- Research hypotheses}

This study will make a comparison between materiality judgments of a group of auditors, credit managers, and financial analysts of to find out whether there is a significant difference between materiality judgments among them, which may indicate an expectation gap regarding materiality of misstatements. Also an attempt will be made to examine whether the disclosure of materiality level used by the auditor will be acceptable to users as a way to narrow the gap, if exists.

In the current study, an experiment is conducted to test the hypotheses:

\section{H1: There is no difference among auditor's assessment and users' assessments of materiality. \\ H2: Disclosure of auditor materiality threshold is not useful to users as a way to narrow the gap, if exist.}




\section{Design of the experiment}

(a) Subjects

The experiment was executed amongst a variety of users of financial statements (sample of financial analysts and credit managers) and sample of independent auditors. Fourteen financial analysts as professional representatives of investors, 24 credit managers as professional representatives of creditors, and 33 CPAs participated in this study.

\section{(b) Experimental Task}

Participants received three short hypothetical cases, and they were asked to respond to three requests in each case:

\section{Case no. 1}

1. What is your assessment of the preliminary judgment about materiality for the entire engagement? (Please use operating income before taxes as a base in your assessment).

2. How much, in your estimate, is the tolerable misstatement (i.e., largest immaterial misstatement) for inventory in this case?

3. According to data in this case, your assessment of preliminary judgment about materiality for the entire engagement and tolerable misstatement, would you consider a 90,000 L.E. overstatement in inventory material?

- Yes, in my estimate, a 90,000 L.E. overstatement in inventory is material.

- No, in my estimate, a 90,000 L.E. overstatement in inventory is not material.

\section{Case no. 2}

1. What is your assessment of the preliminary judgment about materiality for the entire engagement? (Please use operating income before taxes as a base in your assessment). 
2. How much, in your estimate, is the tolerable misstatement (i.e., largest immaterial misstatement) for accounts payable in this case?

3. According to data in this case, your assessment of preliminary judgment about materiality for the entire engagement and tolerable misstatement, would you consider a 25,000 L.E. understatement in accounts payable material?

- Yes, in my estimate, a 25000 L.E. understatement in accounts payable is material.

- No, in my estimate, a 25000 L.E. understatement in accounts payable is not material.

\section{Case no. 3}

1. Would the provision of a "materiality report", such as the one presented above, provide any useful information for you as a user of financial statements?

2. A- Do you agree with the preliminary judgment about materiality for the entire engagement and tolerable misstatement used by the auditor?

B- If you don't agree with the Preliminary judgment about materiality for the entire engagement and tolerable misstatement used by the auditor, how would this affect your reading of the auditor report?

3. Do you consider adding a" materiality report" by the auditor such as the one proposed above, is an acceptable idea?

4. What is the most important argument that may be raised against publishing a materiality report?

\section{(c) Experimental Procedures}

The experiment used two hypothetical companies via three short cases containing summary data from the financial statements with an alleged overstatement in inventories in the first case and an alleged understatement in accounts payable in the second case. Materiality report (i.e., materiality 
disclosure) was proposed and added in the third case. The participants were asked to perform the experimental task. Finally the subjects were asked to fill out an exit questionnaire to indicate their perceptions about materiality thresholds, and sufficiency information provided for making reasonable judgments about materiality.

\section{d) Case development}

Three cases were developed to compare materiality choices of CPAs, credit managers, and financial analysts. Cases are extracts from the financial statements of two hypothetical companies (A and B) and a number of key financial ratios. The financial data in the cases were developed from an actual history of two manufacturing firms. The following is a brief summary of each case:

Case 1- This case contains extracts from the financial statements of a hypothetical company (Co.A), with an alleged overstatement in inventories. All participants were asked to assess the preliminary judgment about materiality for the entire engagement, allocate tolerable misstatement for inventory, and indicate whether the misstatement is material or immaterial.

Case 2- This case contains extracts from the financial statements of another hypothetical company (Co.B), with an alleged understatement in accounts payable. All participants were asked to assess the preliminary judgment about materiality for the entire engagement, allocate tolerable misstatement for accounts payable, and indicate whether the misstatement in accounts payable is material or immaterial.

Case 3- For attainting more transperency of audit results, a materiality report was proposed and added in this case. Subjects were asked to provide their opinions about the proprietary of including such a report after the auditor report, with an explanation of how the auditor applied the concept of 
materiality. Subjects (users) were also asked to assess whether they agree or disagree with the materiality assessments used by the auditor in that case, and how would this affect their reading of the auditor report. Finally, user subjects were asked about the most important argument that may be raised against publishing a "materiality report".

\section{(e) Experimental materials}

The $1^{\text {st }}$ case materials are extracts from the financial statements of a hypothetical company (Co. A), with an alleged overstatement in (inventories) of $(90,000)$ L.E. (Except for the ratios, amounts given are rounded to the nearest L.E. thousand). See table (2) for a complete description of case material.

Table (2)

Extracts from the financial statements of company (A)

\begin{tabular}{|c|c|c|}
\hline $\begin{array}{c}\text { Financial statements } \\
\text { adjusted for alleged } \\
\text { error (2015) } \\
\end{array}$ & $\begin{array}{c}\text { Published financial } \\
\text { statements } \\
(2015) \\
\end{array}$ & \\
\hline $1,301,000$ & $1,391,000$ & Inventories \\
\hline $3,302,000$ & $3,392,000$ & Current assets \\
\hline $9,035,000$ & $9,125,000$ & Total assets \\
\hline $2,823,000$ & $2,913,000$ & Operating income before taxes \\
\hline 213000 & 213000 & Accounts payable \\
\hline $3,313,000$ & $3,313,000$ & Stockholders' equity \\
\hline $\begin{array}{l}6.63 \\
161\end{array}$ & $\begin{array}{l}6.36 \\
168\end{array}$ & $\begin{array}{l}\text { Price/ earnings } \\
\text { Earnings per share }\end{array}$ \\
\hline 0.24 & 0.25 & Return on assets \\
\hline 0.69 & 0.70 & Return on equity \\
\hline 0.358 & 0.363 & Equity- to- assets ratio \\
\hline 0.641 & 0.637 & Debt ratio \\
\hline 1.009 & 1.032 & Current ratio \\
\hline
\end{tabular}




\section{Additional information:}

- No special circumstances exist that might affect materiality judgment and tolerable misstatements. For example, no debt covenants exist that would be affected by inventory misstatements.

- Audit results of previous periods are generally positive.

- Company A's management enjoys good reputation and integrity.

- Company A maintained a constant trend of profit for the preceding 5 years.

The $2^{\text {nd }}$ case materials are extracts from the financial statements of a hypothetical company (Co. B), with an alleged understatement in (Accounts Payable) of (25000) L.E. (Except for the ratios, amounts given are rounded to the nearest L.E. thousand). See table (3) for a complete description of case material.

Table (3)

Extracts from the financial statements of company (B)

\begin{tabular}{|c|c|l|}
\hline $\begin{array}{c}\text { Financial statements } \\
\text { adjusted for alleged } \\
\text { error (2015) }\end{array}$ & $\begin{array}{c}\text { Published financial } \\
\text { statements } \\
(2015)\end{array}$ & \\
\hline $\mathbf{2 , 0 7 5 , 0 0 0}$ & $\mathbf{2 , 0 7 5 , 0 0 0}$ & Inventories \\
\hline $4,704,000$ & $4,704,000$ & Current assets \\
\hline $\mathbf{6 , 2 5 2 , 0 0 0}$ & $\mathbf{6 , 2 5 2 , 0 0 0}$ & Total assets \\
\hline $\mathbf{7 8 1 , 0 0 0}$ & $\mathbf{7 8 1 , 0 0 0}$ & Operating income before taxes \\
\hline $\mathbf{2 8 1 , 0 0 0}$ & $\mathbf{2 5 6 , 0 0 0}$ & Accounts payable \\
\hline $\mathbf{3 , 3 0 3 , 0 0 0}$ & $\mathbf{3 , 3 0 3 , 0 0 0}$ & Stockholders equity \\
\hline 19.72 & $\mathbf{1 9 . 7 2}$ & Price/ earnings \\
\hline $\mathbf{6 . 0 3 6}$ & $\mathbf{6 . 0 3 6}$ & Earning per share \\
\hline $\mathbf{0 . 1 2}$ & $\mathbf{0 . 1 2}$ & Return on assets \\
\hline $\mathbf{0 . 2 3}$ & $\mathbf{0 . 2 3}$ & Return on equity \\
\hline $\mathbf{0 . 5 3}$ & $\mathbf{0 . 5 3}$ & Equity- to- assets ratio \\
\hline 1.68 & 1.69 & Debt ratio \\
\hline $\mathbf{0 . 4 6 9}$ & $\mathbf{0 . 4 6 6}$ & Current ratio \\
\hline & &
\end{tabular}




\section{Additional information:}

- $\quad$ No special circumstances exist that might affect materiality judgment about Accounts payable misstatements and Accounts payable tolerable misstatement.

- $\quad$ Audit results of previous periods are generally positive.

- Company B's management enjoys good reputation and integrity.

- Company B attained a constant trend of profit for the previous 5 years.

The $3^{\text {rd }}$ case materials are determination of balance sheet accounts, tolerable misstatements, and estimated misstatements used by the auditor in each account added in a separate report about materiality (following the auditor report). Subjects are asked to examine the following materiality report:

\section{Materiality report}

Preliminary judgment about materiality for the entire engagement $(10 \%$ of operating income before taxes) $=10 \% * 2,138,400$

$$
=213,840 \text { L.E }
$$

Tolerable misstatements for the balance sheet accounts are determined after taking the following consideriations:

$>$ Relative audit costs of item.

$>$ Possibility of misstatements in item.

$>$ Size of the balance (item).

Table (4) shows tolerable misstatements and estimated misstatements (amounts are rounded to the nearest L.E thousand): 


\begin{tabular}{|c|c|c|c|c|c|c|c|}
\hline $\begin{array}{c}\text { Tolerable } \\
\text { Misst. }\end{array}$ & $\begin{array}{c}\text { Estimated } \\
\text { Misst. } \\
\end{array}$ & Balance & $\begin{array}{l}\text { Liabilities } \\
\text { \& Equity } \\
\end{array}$ & $\begin{array}{l}\text { Tolerabl } \\
\text { e Misst. }\end{array}$ & $\begin{array}{l}\text { Estimate } \\
\text { d Misst. }\end{array}$ & Balance & $\underline{\text { Assets }}$ \\
\hline 52000 & 48800 & 508000 & $\begin{array}{c}\text { Accounts } \\
\text { payable }\end{array}$ & 500 & 600 & 132000 & Cash \\
\hline 23500 & 27000 & 826000 & $\begin{array}{c}\text { Other current } \\
\text { liabilities }\end{array}$ & 54000 & 49000 & 625000 & $\begin{array}{l}\text { Accounts } \\
\text { receivable } \\
\text { (net) }\end{array}$ \\
\hline \multirow[t]{2}{*}{13750} & 16000 & 734000 & $\begin{array}{c}\text { Long-term } \\
\text { liabilities }\end{array}$ & 31400 & 32000 & 1245000 & $\begin{array}{l}\text { Inventories } \\
\text { (net) }\end{array}$ \\
\hline & & 2068000 & Total liabilities & 38000 & 55000 & 143000 & $\begin{array}{l}\text { Other } \\
\text { current } \\
\text { assets } \\
\end{array}$ \\
\hline 22500 & 23000 & 70000 & Allowance & 8300 & 10000 & 1800000 & $\begin{array}{l}\text { Net plant } \\
\text { assets }\end{array}$ \\
\hline$-0-$ & $-0-$ & 280000 & Capital & 19050 & 22500 & 807000 & $\begin{array}{l}\text { Other } \\
\text { long-term } \\
\text { assets }\end{array}$ \\
\hline $\begin{array}{c}\text { Not } \\
\text { applicable }\end{array}$ & $\begin{array}{c}\text { Not } \\
\text { applicable }\end{array}$ & 714000 & $\begin{array}{l}\text { Retained } \\
\text { earnings }\end{array}$ & & & & \\
\hline 7700 & 8000 & 1365000 & Reserves & & & & \\
\hline \multirow[t]{3}{*}{2600} & 3000 & 255000 & $\begin{array}{c}\text { Minority } \\
\text { interest }\end{array}$ & & & & \\
\hline & & 2684000 & Total equity & & & & \\
\hline & & 4752000 & $\begin{array}{c}\text { Total liabilities } \\
\text { \& equity }\end{array}$ & & & $\underline{4752000}$ & Total assets \\
\hline
\end{tabular}

Total estimated misstatements

$\underline{273,350 \text { L.E }}$

Preliminary judgment about materiality for the entire engagement 213,840 L.E

Preliminary decision: Because total estimated misstatements (273,350 L.E) are greater than preliminary judgment about materiality for the entire engagement, 
the auditor decided to reject the balances and required management to adjust the balances which have estimated misstatements greater than tolerable misstatement; i.e.,

Accounts Receivable.

$>$ Accounts Payable.

Management agreed, and made the adjustments: therefore, the auditor issued an "unqualified opinion ".

\subsection{Experimental results (findings)}

The results are based on three experimental cases, where 71 participants responded to three basic questions in each case. I direct my analysis to: (1) materiality judgment gap; (2) the extent to which users of the financial statements accept the disclosure of auditor materiality threshold.

\subsubsection{Materiality judgment gap}

First hypothesis, (H1), focuses on materiality judgment, which predicts that auditor's assessment of materiality will not differ from users' assessments. For the purpose of statistical analysis, T-test has been used to compare financial analysts' materiality assessments and credit managers' materiality assessments in order to determine the likelihood of combining the two groups or investigating them separately. Table (9) present basic statistical results. As can be seen, the examination of means indicates that materiality assessments of the two groups did not differ; the test yielded statistically insignificant different assessments of materiality thresholds between the users of financial statements (credit managers and financial analysts).

With regard to case 1 ( inventory overstatement case), credit managers determine preliminary judgment about materiality with an average of 148023.75 L.E., while financial analysts report average preliminary judgment about materiality at 153859.64 L.E., with t- statistic of (-.212). It appears to have insignificant difference in assessing planning materiality between the 
two groups at level 0.1. Similarly, credit managers and financial analysts report tolerable misstatement for inventory with average 45908.33 L.E. and 33407.71 L.E. respectively, with t- statistic of (1.090). It appears to have insignificant difference in allocating tolerable misstatement between the two groups at level 0.1. With regard to case 2 (accounts payable understatement case), credit managers determine preliminary judgment about materiality with an average of 47909.17 L.E., while financial analysts report average preliminary judgment about materiality at 41513.93 L.E., with t- statistic of (.392). It appears to have insignificant difference in assessing planning materiality between the two groups at level 0.1 . However, credit managers and financial analysts report tolerable misstatement for accounts payable with average 16616.67 L.E. and 7711.29 L.E. respectively, with t- statistic of (2.536). It appears to have significant difference in allocating tolerable misstatement between the two groups at level 0.05 . Hence, financial analysts and credit managers were combined in one group, i.e., 'users group'.

Table (9)

Summary of statistical results for 'users group'

\begin{tabular}{|c|c|c|c|l|}
\hline \multirow{2}{*}{ Sig. } & \multirow{2}{*}{$\mathrm{t}$} & \multicolumn{2}{|c|}{ Mean } & \multirow{2}{*}{ Variables } \\
\cline { 3 - 4 } & & $\begin{array}{c}\text { Financial } \\
\text { analysts } \\
(\mathrm{n}=14)\end{array}$ & $\begin{array}{c}\text { Credit } \\
\text { managers } \\
(\mathrm{n}=24)\end{array}$ & \\
\hline .833 & -.212 & 153859.64 & 148023.75 & $\begin{array}{l}\text { Case 1:Preliminary } \\
\text { judgment }\end{array}$ \\
\hline .284 & 1.090 & 33407.71 & 45908.33 & $\begin{array}{l}\text { Case 1: Tolerable } \\
\text { misstatement }\end{array}$ \\
\hline .698 & .392 & 41513.93 & 47909.17 & $\begin{array}{l}\text { Case 2:Preliminary } \\
\text { judgment }\end{array}$ \\
\hline .016 & 2.536 & 7711.29 & 16616.67 & $\begin{array}{l}\text { Case 2: Tolerable } \\
\text { misstatement }\end{array}$ \\
\hline$* *$
\end{tabular}

Notes: $(*)$ and $(* *)$ Denote the significance of the parameter estimated at the $0.01,0.05$ levels, respectively. 
Then, I perform an independent samples test to examine whether auditor's assessment of materiality differ from users' assessments. The first case, inventory overstatement case, yielded (suggested) statistically significant different responses as to appropriate materiality threshold. Table (10) presents basic statistical results of the case. The examination of means indicates that users of financial statements have lower materiality thresholds than auditors, with an average of 150173.82 L.E. when assessing planning materiality (preliminary judgment about materiality for the entire engagement). CPAs register higher mean at 192002.73 L.E., with t- statistic of (-2.391). It appears to have significant difference in determining planning materiality between the two groups at level 0.05. Similarly, users and auditors report tolerable misstatement for inventory with average 15302.84 L.E., and 23131.27 L.E. respectively, with $\mathrm{t}$ - statistic of $(-1.145)$. It appears to have significant difference in allocating tolerable misstatement between the two groups at level 0.1. This is consistent with prior observations of most prior research ( i.e., Woolsey (1954), Pattillo (1976), Holstram and Messier (1982), and Hojskov (1998)) that there is a significant difference between auditors' and users' assessments of materiality threshold.

Table (10)

Summary of experimental results - case (1)

\begin{tabular}{|c|c|c|c|c|}
\hline \multirow{2}{*}{ Sig. } & \multirow{2}{*}{$\mathrm{t}$} & \multicolumn{2}{|c|}{ Mean } & \multirow{2}{*}{ Variables } \\
\cline { 3 - 4 } & & $\begin{array}{c}\text { Users } \\
(\mathrm{n}=38)\end{array}$ & $\begin{array}{c}\text { Auditors } \\
(\mathrm{n}=33)\end{array}$ & \\
\hline $0.020 * *$ & -2.391 & 150173.82 & 192002.73 & $\begin{array}{l}\text { Preliminary judgment } \\
\text { about materiality }\end{array}$ \\
\hline $0.081 * * *$ & -1.145 & 15302.84 & 23131.27 & $\begin{array}{l}\text { Tolerable misstatement } \\
\text { for inventories }\end{array}$ \\
\hline
\end{tabular}

Notes: $(* *)$ and $(* * *)$ Denote the significance of the parameter estimated at the 0.05 , 0.10 levels, respectively. 
With regard to question (3) in case (1), all subjects were asked to indicate whether the inventory misstatement is material or immaterial. Chisquare test is used to determine the materiality assessment for inventory misstatement. Table (11) presents statistical results of materiality assessment for inventory misstatement (material / immaterial). All user samples (38) consider the inventory misstatement as a material misstatement. However, $21.2 \%$ of auditor samples consider the inventory as immaterial misstatement. There is a significant difference between auditors' and users' materiality assessments for inventory misstatement at level 0.01 .

Table (11)

Summary of materiality assessments for inventory misstatement

\begin{tabular}{|c|c|c|c|c|c|}
\hline \multirow{2}{*}{ Sig. } & \multirow{2}{*}{$\begin{array}{l}\text { Chi- } \\
\text { square }\end{array}$} & \multicolumn{2}{|c|}{ Mean } & & \\
\hline & & $\begin{array}{c}\text { auditors } \\
(\mathrm{n}=33)\end{array}$ & $\begin{array}{l}\text { Users } \\
(\mathrm{n}=38)\end{array}$ & & \\
\hline \multirow{2}{*}{$0.009 *$} & \multirow{2}{*}{6.744} & $\begin{array}{c}7 \\
21.2 \%\end{array}$ & $\begin{array}{c}0 \\
0 \%\end{array}$ & $\begin{array}{l}\text { No count } \\
\text { \% within } \\
\text { sample }\end{array}$ & \multirow{2}{*}{$\begin{array}{c}\text { Case } 1 \\
\text { Q } 3\end{array}$} \\
\hline & & $\begin{array}{c}26 \\
78.8 \%\end{array}$ & $\begin{array}{c}38 \\
100 \%\end{array}$ & $\begin{array}{l}\text { Yes count } \\
\text { \% within } \\
\text { sample }\end{array}$ & \\
\hline
\end{tabular}

Notes: $(*)$ and $(* *)$ Denote the significance of the parameter estimated at the $0.01,0.05$ levels, respectively.

The Second case, accounts payable understatement case, yielded (suggested) statistically insignificant different responses of materiality assessment between auditors and users of the financial statements. Table (12) presents basic statistical results of the case. The examination of means indicates that Judgments of the two groups did not differ. Auditors assess preliminary judgment about materiality with an average of 60816.67 L.E., while users of the financial statements assess preliminary judgment about 
materiality with an average of 45553.03 L.E., with $\mathrm{t}$ - statistic of (-1.580). It appears to have insignificant difference in determining planning materiality between the two groups at level 0.1. This is consistent with Bootsman and Robertson (1974), and Chewing et al. (1998) study, which document auditors and users judgments to be similar. However, auditors and users report tolerable misstatement for accounts payable with average 13335.74 L.E., and 6646.79 L.E. respectively, with t- statistic of (-2.801). It appears to have significant difference in allocating tolerable misstatement between the two groups at level 0.01.Users demonstrated a significant lower materiality threshold than auditors.

Table (12)

Summary of experimental results - case (2)

\begin{tabular}{|c|c|c|c|c|}
\hline \multirow{2}{*}{ Sig. } & \multirow{2}{*}{$\mathrm{t}$} & \multicolumn{2}{|c|}{ Mean } & \multirow{2}{*}{ Variables } \\
\cline { 3 - 4 } & & $\begin{array}{c}\text { Users } \\
(\mathrm{n}=38)\end{array}$ & $\begin{array}{c}\text { Auditors } \\
(\mathrm{n}=33)\end{array}$ & \\
\hline 0.119 & -1.580 & 45553.03 & 60816.67 & $\begin{array}{c}\text { Preliminary judgment } \\
\text { about materiality }\end{array}$ \\
\hline $0.007 *$ & -2.801 & 6646.79 & $\begin{array}{c}13335.7 \\
4\end{array}$ & $\begin{array}{c}\text { Tolerable misstatement for } \\
\text { accounts payable }\end{array}$ \\
\hline
\end{tabular}

Notes: $\left(^{*}\right)$ and $(* *)$ Denote the significance of the parameter estimated at the $0.01,0.05$ levels, respectively.

With regard to question (3) in case (2), all subjects were asked to indicate whether the accounts payable misstatement is material or immaterial. Chi-square test is used to determine the materiality assessment for accounts payable misstatement. Table (13) presents statistical results of materiality assessment for accounts payable misstatement (material / immaterial). There is a significant difference between auditors' and users' materiality assessments for accounts payable misstatement at level 0.05 . 
Table (13)

Summary of materiality assessments for accounts payable misstatement

\begin{tabular}{|c|c|c|c|l|c|}
\hline \multirow{2}{*}{ Sig. } & \multirow{2}{*}{$\begin{array}{c}\text { Chi- } \\
\text { square }\end{array}$} & $\begin{array}{c}|c| \\
\text { auditors } \\
(\mathrm{n}=33)\end{array}$ & $\begin{array}{c}\text { Users } \\
(\mathrm{n}=38)\end{array}$ & \multicolumn{2}{|c|}{} \\
\hline \multirow{2}{*}{$0.013^{* *}$} & \multirow{2}{*}{6.137} & 7 & 2 & $\begin{array}{c}\text { No count } \\
\% \text { within } \\
\text { sample }\end{array}$ & Case 2 \\
\cline { 3 - 5 } & & $21.2 \%$ & $5.26 \%$ & $\begin{array}{c}\text { Yes count } \\
\%\end{array}$ & Q within \\
& & $78.8 \%$ & $94.74 \%$ & sample & \\
\hline
\end{tabular}

Notes: $(*)$ and $(* *)$ Denote the significance of the parameter estimated at the $0.01,0.05$ levels, respectively.

In summary, the results reject the null hypothesis $(\mathrm{H} 1)$ that auditors and users of the financial statements have equal assessments of materiality, which indicates the existence of materiality judgment gap.

Table (14) presents basic statistical results. With regard to case 3, subjects agree that the provision of a "materiality report" will provide useful information for them, and adding it after auditor report will be an acceptable idea. It appears to have significant agreement among subjects at level 0.01 . However, with regard to question 2, subjects have divided opinions about materiality threshold used by the auditor in this case. Nineteen subjects agree with the preliminary judgment about materiality and tolerable misstatement used by the auditor. On the contrary, eighteen subjects disagree with auditor's materiality thresholds in this case.

In summary, the results reject the null hypothesis $(\mathrm{H} 2)$, that users of the financial statements do not accept the disclosure of auditor materiality threshold. 
Table (14)

Summary of experimental results - case (3)

\begin{tabular}{|c|c|c|c|c|c|c|}
\hline \multirow{2}{*}{ Sig. } & \multirow{2}{*}{$\begin{array}{l}\text { Chi- } \\
\text { square }\end{array}$} & \multicolumn{2}{|c|}{ No } & \multicolumn{2}{|c|}{ Yes } & \multirow{2}{*}{ Items } \\
\hline & & $\%$ & $\mathbf{n}$ & $\%$ & $\mathbf{n}$ & \\
\hline $0.000 *$ & 23.684 & 0.11 & 4 & 0.895 & 34 & $\begin{array}{l}\text { 1-Would the provision of a } \\
\text { "materiality report", such as } \\
\text { the one presented above, } \\
\text { provide any useful information } \\
\text { for you as a user of financial } \\
\text { statements? }\end{array}$ \\
\hline 0.869 & 0.027 & 0.49 & 18 & 0.51 & 19 & $\begin{array}{l}\text { 2-Do you agree with the } \\
\text { preliminary judgment about } \\
\text { materiality for the entire } \\
\text { engagement and tolerable } \\
\text { misstatement used by the } \\
\text { auditor? }^{(2)}\end{array}$ \\
\hline 0.000* & 30.421 & 0.053 & 2 & 0.947 & 36 & $\begin{array}{l}\text { 3-Do you consider adding a" } \\
\text { materiality report" by the } \\
\text { auditor such as the one } \\
\text { proposed above, is an } \\
\text { acceptable idea? }\end{array}$ \\
\hline
\end{tabular}

Notes: $(*)$ and $(* *)$ Denote the significance of the parameter estimated at the $0.01,0.05$ levels, respectively.

\section{Conclusions}

The results indicate a lack of consensus among auditors and users of the financial statements. There are significantly different views of materiality exist across different cases. One area of variability is establishing planning materiality judgment. Subjects in this study were asked to use operating income before taxes as a base in assessing preliminary judgment about materiality. The results indicate that there were different assessments of 
materiality among groups, which means that the percentage of income which used to establish planning materiality is different among groups included in the study.

To summarize, the goal of this study is to provide an answer to two questions: (1) Does the auditor's assessment of materiality differ from the user's assessment of materiality which may indicate a materiality judgment gap? and, (2) If so, does the disclosure of materiality level used by the auditor will be acceptable to users as a way to narrow this gap?

These questions are answered affirmatively; a significant materiality judgment gap between auditors and users of the financial statements does exist. Users of the financial statements strongly agree with the disclosure of auditor materiality and called for a "materiality report" as a way to alleviate the impact of the materiality judgment gap.

\section{REFERENCES}

American Institute of Certified Public Accountants. 1983. Audit Risk and Materiality in Conducting an Audit. Statement on Auditing Standard no. 47 New York, NY: AICPA.

American Institute of Certified Public Accountants. 2005b. letter of comment on the IAASB's Exposure Draft, proposed international standard on Auditing (ISA) 320 (Revised), Materiality in the Identification and Evaluation of Misstatements. May 17. New York, NY: AICPA.

Arens, A. A., Elder, R. J., Beasley, M. S., \& Jenkins, G. J. (2006). Auditing and assurance services: an integrated approach. Englewood Cliffs, NJ: Pearson Prentice Hall. 
Azzopardi, J., \& Baldacchino, P. (2009). The concept of audit materiality and attitudes towards materiality threshold disclosure among Maltese audit practitioners. Bank of Valletta Review, (40).

Big Five Audit Materiality task force. 1998. Report of the Big Five Audit Materiality task force. New York, NY: AICPA.

Blokdijk, H., Drieenhuizen, F., Simunic, D. A., \& Stein, M. T. (2003). Factors affecting auditors' assessments of planning materiality. Auditing: A Journal of Practice \& Theory, 22(2), 297-307.

Boatsman, J. R., \& Robertson, J. C. (1974). Policy-capturing on selected materiality judgments. The Accounting Review, 49(2), 342-352.

Brown, L.D.(1993).Earnings forecasting research:Its implications for capital markets research. International Journal of Forecasting, 9(3),295-320.

Chewning Jr, E. G., Wheeler, S. W., \& Chan, K. C. (1998). Evidence on auditor and investor materiality thresholds resulting from equity-for-debt swaps.Auditing, 17(1), 39.

Cho, S. Y., Hagerman, R. L., Nabar, S., \& Patterson, E. R. (2003). Measuring stockholder materiality. Accounting horizons, 17, 63.

Davis, S. M. (2003). Market Response to Auditor's Reports: A Reexamination of Auditor Materiality Thresholds (Doctoral dissertation, Washington University).

Elder, R. J., \& Allen, R. D. (1998). An empirical investigation of the auditor's decision to project errors. Auditing, 17(2), 71.

Financial accounting standards Board (FASB). 1975. Materiality. Discussion Memorandum. Stamford. CT: FASB.

Firth, M. (1979). Consensus views and judgment models in materiality decisions. Accounting, Organizations and Society, 4(4), 283-295. 
Fisher, D. H. (1987). Knowledge acquisition via incremental conceptual clustering. Machine learning, 2(2), 139-172.

Fisher, M. H. (1990). The effects of reporting auditor materiality levels publicly, privately, or not at all in an experimental markets setting. Auditing: A Journal of Practice and Theory, 9, 184-222.

Holstrum, G. L., \& Messier Jr, W. F. (1982). A review and integration of empirical research on materiality. Auditing: A Journal of Practice and Theory, 2(1), 45-63.

Højskov, L. (1998). The Expectation Gap between Users' and Auditors' Materiality Judgements in Denmark, Working Paper at Southern Denmark Business School, 1-23.

International accounting standards Board (IASB). International Accounting standard (IAS) 1- presentation of financial statements.

Jennings, M., Kneer, D. C., \& Reckers, P. M. (1987). A reexamination of the concept of materiality- views of auditors, users, and officers of the court. Auditing, journal of practice \& theory, 6 (2), 104-115.

Jennings, M. M., Reckers, P. M., \& Kneer, D. C. (1991). The auditor's dilemma: The incongruous judicial notions of the auditing profession and actual auditor practice. American Business Law Journal, 29(1), 99-126.

Kaplan, S., \& Reckers, P. M. (1995). Auditors' reporting decisions for accounting estimates: the effect of assessments of the risk of fraudulent financial reporting. Managerial Auditing Journal, 10(5), 27-36.

Kinney Jr, W. R., \& Leisenring, J. J. (1983). Using materiality in audit planning. A practical way to relate the auditor's materiality estimate to the design of audit procedures. Journal of Accountancy (pre-1986),155(3), 42. Kranacher, M. (2007). Determining materiality: Relativity and professional judgement. The CPA Journal, 77(8), 80. 
Levitt, A. (1998). Remarks by chairman Arthur Levitt, Securities and Exchange Commission, The numbers game. NYU Center for Law and Business, New York, NY.

De Martinis,M.R.,\& Burrowes,A.W.(1996).Materiality and risk judgements: A review of users' expectations. Managerial Finance, 22(9), 16-34.

McKee, T. E., \& Eilifsen, A. (2000). Current materiality guidance for auditors.

Messier Jr, W. F., Martinov-Bennie, N., \& Eilifsen, A. (2005). A review and integration of empirical research on materiality: Two decades later. Auditing: A Journal of Practice \& Theory, 24(2), 153-187.

Montoya del Corte, J., Martínez García, F. J., \& Fernández Laviada, A. (2010). Effective use of qualitative materiality factors: evidence from Spain.Managerial Auditing Journal, 25(5), 458-483.

Nederland Institute of Register Accountants (NIVRA).2007. (Http://wwwnivra.nl/HRA/index.htm(8September2007)

Pattillo, J. W. (1975). Materiality: the (formerly) elusive standard. Financial Executive, 43, 20-27.

Porter, B. (1993). An empirical study of the audit expectation-performance gap. Accounting and business research, 24(93), 49-68.

Roberts, R. W., \& Dwyer, P. D. (1998). An analysis of materiality and reasonable assurance: professional mystification and paternalism in auditing. Journal of business ethics, 17(5), 569-578.

Robinson, C., \& Fertuck, L. (1985). Materiality, an empirical study of actual auditor decisions (No. 12). Canadian Certified General Accountants' Research Foundation.

Selley, D. (1984). The Origin and Development of Materiality as an Audit Concept. In Auditing Symposium VII (pp. 1-30). 
Shaikh, J. M., \& Talha, M. (2003). Credibility and expectation gap in reporting on uncertainties. Managerial auditing journal, 18(6/7), 517-529.

Steinbart, P. J. (1987). The construction of a rule-based expert system as a method for studying materiality judgments. Accounting Review, 97-116.

Turner, J. L. (2003). Aligning auditor materiality choice and the needs of a reasonable person. Journal of Forensic Accounting, 8, 29-52.

Waters, J. M., \& Tiller, M. G. (1997). Auditors' materiality thresholds: some empirical findings based on real data. American business review, 115-119.

Woolsey, S. M. (1954). Development of criteria to guide the accountant in judging materiality. Journal of Accountancy (pre-1986), 97(2), 167.

Woolsey, S. M. (1973). Approach to solving the materiality problem. Journal of Accountancy, 136(3), 47-50.

Vadivel, V. S. (2004). Audit Materiality and Risks An Overview. Chartared Accountants, 724-729. 